Information Management and Business Review

Vol. 2, No. 6, pp. 276-286, June 2011

\title{
Electronic Commerce Applications among Indian Small and Medium Enterprises
}

\author{
${ }^{1}$ Asghar Afshar Jahanshahi, ${ }^{*}$ Mohammad Ali Hajizadeh Gashti, ${ }^{3}$ Seyed Mohammad Sadeq Khaksar, \\ ${ }^{1}$ Bairagi Kachardas Pitamber \\ 1Department of Commerce \& Research Center, University of Pune, India \\ ${ }^{2}$ Faculty of Management and Human Resource Development, Universiti Teknologi Malaysia, Malaysia \\ ${ }^{3}$ Information Technology Management, University of Sistan \& Bluchestan, Iran \\ *afsharasghar@yahoo.com
}

\begin{abstract}
The cutting edge for business today is electronic commerce. The main vehicle of electronic commerce unequivocally is the Internet and the World Wide Web. With the rapid advancement in the Internet software and hardware and the infrastructure, the electronic commerce is also becoming more and more popular. Many large corporations, small and medium companies and individuals are investing more and more in the Internet business. The main purpose of this paper is to study the effect of e-commerce applications on the operational performance of small and medium enterprises. There are many different types of e-commerce usages that may influence operational performances; in this research we group them according to five different categories: electronic advertising, payment system, marketing, customer support service, order and delivery. For analyzing the data derived from questionnaire, Goodness of Fit Tests and Structural Equation Modeling/Path Analysis were used and the software's which has been used for analyzing the data were LISREL 8.54 and SPSS 18. Survey is considered to be the most appropriate and suitable for this study. According to statistical analysis in this research the results indicates that the electronic commerce applications has been influential on the operational performance in the Indian SMEs.
\end{abstract}

Keywords: Electronic Commerce, Small and Medium Enterprise, Operational Performance, Organizational Performance

\section{Introduction}

In most countries, small and medium enterprises are the backbone of the economy. According to Schaper and Volery (2004), small businesses are important to all national economies because they provide employment opportunities for people, the next generations of large firms, competition, innovation, an outlet for entrepreneurial activity, exports, specialized products and services, support to big business, decentralization, distributions of economics resources, wealth and opportunities and flexibility in the overall economy (Ababulgu, and Islam, 2007). This study focuses on small and medium Enterprises for two key reasons. First, they are important to economic development in developing countries such as India. The second reason to focus on small and medium Enterprises is that they are in a very good position to adapt to new technology like ecommerce; they may be able to adapt faster than larger companies that can slowed by bureaucracy and stricter staffing hierarchies. Use of ICT in business has been able to make valuable strides towards achieving the goals of organizations that indeed has increased customer satisfaction and profitability. Researchers introduce applying the ICT in business as electronic commerce. Generally, the application of electronic commerce by small and medium enterprises in India is proceeding at a normal rate. E-commerce applications are such as electronic Marketing (Duffy, 2005), ad e (Wang, et al., 2009; Mazandarani, 2010) customer support services (Molla and Licker, 2001), electronic ordering and delivery (Senn, 2000) and electronic payment systems (Hua and Guan, 2000). The impact of business performance has introduced e-commerce as a new business approach toward customer satisfaction profitability. Operational performance of a company is related to activities that improve efficiency and effectiveness of business activities.

Eid (2011) studied the use of e-commerce in business management and concluded that the use of electronic commerce mechanisms is effective on market share and customer satisfaction of the companies. Other studies conducted by Allen and Fjermestad (2001) showed that electronic commerce applications had a high impact on new products development and product quality improvement which itself increases the market share and customer satisfaction. Stroehle (2008) was of the opinion that the application of electronic 
commerce in the industry is influential on the improvement of the effectiveness of marketing activities. All these cases show the effectiveness of e-commerce applications on the improvement of operational performance of business. Application of electronic commerce and its impact on operational performance has been confirmed in the investigation of many researchers, in this research a great deal of efforts and time has been exerted to discover that whether this relationship is successful in the small and medium enterprises in India. In this paper, aspects of the initial investigation into the relationship between e commerce applications and operational performance in Indian small and medium enterprises are presented.

\section{Review of Literature}

Small and Medium Enterprises in India : In most developing countries, small and medium enterprises constitute the bulk of the industrial base and contribute significantly to their exports as well as to their GDP or GNP. For instance, India has nearly three million SMEs, which account for almost 50 per cent of industrial output and 42 per cent of India's total exports. It is the most important employment-generating sector and is an effective tool for promotion of balanced regional development (Marg, 2001). The definition of SMEs varies in different countries and studies but is usually based on employment, assets, turnover and the balance sheet total (Burns, 2001; Seyal and Rahman, 2003). The following table shows definition of small and medium enterprise by number of employees in different countries of the world.

Table 1: Definitions of SMEs by number of Employees

\begin{tabular}{lccccc}
\hline Country & Small & Medium & Country & Small & Medium \\
\hline United Kingdom & 50 & 250 & Canada & 50 & $50-500$ \\
Poland & 50 & $50-250$ & Brunei & 10 & $10-100$ \\
Australia & 20 & $21-200$ & Austria & 50 & $50-250$ \\
The Philippines & $10-99$ & $100-199$ & Iran & 50 & $50-250$ \\
Thailand & 50 & $50-200$ & Albania & $10-40$ & $50-250$ \\
Hungary & $11-50$ & $51-250$ & Slovakia & $1-24$ & $25-500$ \\
Romania & $1-20$ & $21-200$ & Uzbekistan & 300 & $300-1,000$ \\
\hline
\end{tabular}

As a legacy of Gandhian philosophy, since independence the small and medium sectors have played an important role in the economic development of India (Gupta, 2006). Enterprise in India is broadly classified into two categories: 1) Manufacturing and 2) those engaged in providing/rendering of services. The" Micro, Small and Medium Enterprises Development (MSMED) Act, 2006" is the first Act for MSMEs which, provides for establishment of a statutory National Board for Micro, Small and Medium Enterprises, filing of memoranda, measures for promotion, development and enhancement of competitiveness of MSMEs, credit facilities, procurement preference and provisions related to delayed payments to micro and small enterprises. The medium sector has been defined for the first time in India and Micro enterprises have been defined for the first time in this Act. Under the MSMED Act 2006, the earlier, rather limited, concept of 'Industries' has been widened to that of 'Enterprises'. Enterprises have been classified broadly into two categories, namely enterprises engaged in the manufacture/production of goods pertaining to any industry; \& enterprises engaged in providing/rendering of services. Enterprises have been defined in terms of investment in plant and machinery/ equipment (excluding land \& building) as below:

Table 2(a): Definitions before 2 October 2006

\begin{tabular}{ccc}
\multicolumn{2}{c}{ Investment ceiling for plant, machinery or fixed assets (land \& building) } \\
Classification & Manufacturing enterprises & Service enterprises \\
\hline Micro & Up to Rs. 2.5 million (US $\$ 50,000)$ & Up to 1 million Rs. $(\$ 20,000)$ \\
Small & Between $2.5 \& 10$ million Rs $(\$ 50,000 \& \$ 0.20$ & Up to 1 million Rs. $(\$ 20,000)$ \\
Medium & Not defined before 2006 & Not defined before 2006 \\
\hline
\end{tabular}

(Ravi, 2009) 
Table 2(b): Definitions after 2 October 2006

\begin{tabular}{|c|c|c|}
\hline Investment & $\begin{array}{c}\text { for plant, machinery or equipments } \\
\text { Manufacturing Enterprises* }\end{array}$ & Service Enterprises** \\
\hline Micro & Up to Rs. 2.5 million (US\$ 50,000) & Up to Rs. 1 million (US\$ 20,000) \\
\hline Small & Rs. 2.5 to Rs. 50 million / (US $\$ 1$ million) & Rs 1 to 20 million Rs (US\$ \\
\hline Medium & Rs. 50 million to Rs. 100 million (US $\$ 2$ & Rs 20 to 50 million Rs (US\$ 1 \\
\hline
\end{tabular}

The below Graph describes the composition of the MSME in India. This Graph also highlights the decomposition of MSME units based on nature of activity. In the sector as a whole, about 33 percent of enterprises are engaged in services sector and majorities of enterprises are in the manufacturing space (67 percent).

\section{Graph 1: Describes the composition of the MSME in India}

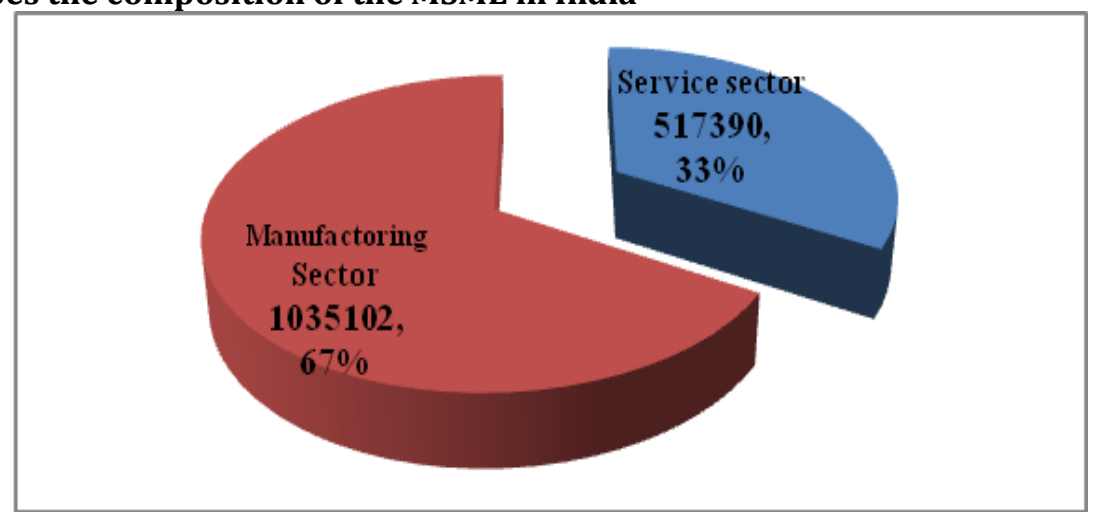

Data source: (Annual Reports, Ministry of MSMEs, 2009-10; Afshar et al. 2010b)

Electronic commerce applications: E-commerce is changing all business functional areas and their important tasks, ranging from advertising to paying bills. Electronic commerce has attracted significant attention in the last few years. This high profile attention has resulted in significant progress towards strategies, requirements, and development of e-commerce applications (Upkar, 2002; Kalakota and Robinson, 1999 and Afshar et al, 2010). The earliest electronic commerce studies can be traced back to those published in 1994 (Cronin et al., 1994; Barker, 1994). Barker (1994) provided one of the first surveys on how small businesses used the Internet for business purposes.

Cronin et al. (1994) discussed how e-commerce might change how competitive intelligence was being gathered. They also discussed briefly how small businesses could benefit from such a tool. In the next year or so, more research was published focusing on SMEs and e-commerce (e.g., Cockburn \& Wilson, 1995; Fuller \& Jenkins, 1995; Poon \& Swatman, 1995). Since then, much has been published from the perspective of information systems, marketing, and management (Cited in Poon and Huang, 2004). Turban et al. (2002) define e-commerce as: "An emerging concept that describes the process of buying, selling, or exchanging services and information via computer networks". Raymond (2001) defines e-commerce as: "The functions of information are exchange and commercial transaction support that operate on telecommunications networks linking business partners (typically customers and suppliers)." Although there are many different types of ecommerce applications, we can group them according to categories. The following table shall describe five different categories of electronic commerce applications in small and medium enterprises. 
Table 3: Various Applications of E commerce

\begin{tabular}{|c|c|c|}
\hline $\begin{array}{l}\text { Different Applications } \\
\text { of E commerce }\end{array}$ & Description & Researchers \\
\hline Electronic Advertising & $\begin{array}{ll}\text { - } & \text { Provide product information to customers } \\
\text { - } & \text { Displaying company information on website } \\
\text { - } & \text { Online electronic brochures or buying guides } \\
\text { - } & \text { Display only a range a products which are } \\
& \text { relevant to the particular customer }\end{array}$ & $\begin{array}{l}\text { Block et al. (1996) } \\
\text { Ainin \& Jaffar (2003) } \\
\text { Soh et al. (1997) }\end{array}$ \\
\hline $\begin{array}{l}\text { Electronic Customer } \\
\text { Support Service }\end{array}$ & $\begin{array}{ll}\text { - } & \text { Online help- Frequently Asked Question } \\
\text { - } & \text { Online products update } \\
\text { - } & \text { Handling customers feedback/queries online } \\
\text { - } & \text { Online application/registration } \\
& \text { Personalized email communication }\end{array}$ & $\begin{array}{l}\text { Turban et al. (2000) } \\
\text { Ainin (2000) } \\
\text { Fatimah et al. }(2000)\end{array}$ \\
\hline Electronic Marketing & $\begin{array}{l}\text { - } \quad \text { Allowing a customer to contact a sales office } \\
\text { Share information with competitors, customers } \\
\text { and suppliers } \\
\text { - Using internet to find out customers' needs and } \\
\text { wants } \\
\text { - Using internet for anticipating customer needs } \\
\text { - Achieving customer satisfaction through the } \\
\text { electronic channel }\end{array}$ & $\begin{array}{l}\text { Arie et al. }(1995) \\
\text { Block et al. (1996) } \\
\text { Johnson (2003) } \\
\text { Kotler, (2000) } \\
\text { Smith \& Chaffey (2005) }\end{array}$ \\
\hline $\begin{array}{l}\text { Electronic Payment } \\
\text { System }\end{array}$ & $\begin{array}{ll}\text { - } & \text { Electronic Fund Transfer(EFT) } \\
\text { - } & \text { Online credit card processing } \\
\text { - } & \text { Electronic money } \\
& \text { Smart and prepaid card }\end{array}$ & $\begin{array}{l}\text { Lawal (2010) } \\
\text { Block et al. (1996) } \\
\text { Zwass (1998) } \\
\text { Fatimah } \text { et al. ( 2000) }\end{array}$ \\
\hline $\begin{array}{l}\text { Electronic Order and } \\
\text { Delivery }\end{array}$ & $\begin{array}{ll}\text { - } & \text { Coordinating procurement with suppliers } \\
\text { - } & \text { Online } \\
\text { - } & \text { On-line ordering of software products } \\
\text { - } & \text { Tracking incoming and outgoing goods delivery } \\
\text { - } & \text { Online order entry and delivery } \\
\text { - } & \text { Electronic Data Interchange(EDI) }\end{array}$ & $\begin{array}{l}\text { Johnson (2003) } \\
\text { Oakes (2002) } \\
\text { Turban et al. }(2000) \\
\text { Fahri \& Omar (2001) }\end{array}$ \\
\hline
\end{tabular}

E-commerce offers lower costs per business transaction, especially with respect to mailing and paper costs (Lawal, 2010). Fewer mistakes occur in paperwork because fewer people handle the data (Johnson, 2003). Customer satisfaction is heightened due to better access to order and promotional data. The old rules are breaking down. Companies now share information with competitors, producing "competition". Suppliers and buyers share information: Economic and Cultural boundaries are disappearing - in some market segments businesses must be global (Johnson, 2003). Generally, in the electronic commerce research literature, greater levels of electronic commerce adoption have been linked with improved organizational performance (Nickels et al., 2007 and Kraemer et al., 2002). Berrill et al. (2004) believes that Companies that adopt internet technology in various activities are aware of this benefit and hope to improve competitive advantage, communication, and products and services when they adopt e-commerce.

Concepts of operational performance as a part of organizational performance: Many SMEs are becoming ever more focused on their organizational performance. Organizational performance comprises the actual results or output of an organization as measured against its intended results or outputs. Typically, there are different ways to characterize various types of organizational performance in small and medium sized enterprises. The following paragraph briefly shows the different types of them. Dyer and Reeves (1995), proposed four possible types of measurement for organizational performance in small and medium-sized manufacturing firms: 1) human resource outcomes (job satisfaction, absenteeism, turnover), 2) organizational outcomes (quality, productivity, service), 3) financial accounting outcomes (Return on assets, profitability), and 4) capital market outcomes, (stock price, growth, returns). Pierre et al. (2009) argued that 
organizational performance encompasses three specific areas of firm outcomes: (a) financial performance (profits, return on assets, return on investment, etc.); (b) product market performance (sales, market share, etc.); and (c) shareholder return (total shareholder return, economic value added, etc.) According to Shaker and Basem (2010) organizational performance indicators from relationship marketing perspective are included: Increasing market Share, Retaining current customers, Attracting new customers, creating loyal customers, Increasing profit, Increasing return on investment, Positive image. Venkatrman and Ramanujam (1986) argued that organizational performance have three dimensions: financial performance, operational performance, and stakeholder performance. According to literature review, most common types of organizational performance measures that used in recent empirical research are included: Financial and accounting performance, operational performance and market-based performance (Brealey et al., 2001; Higgins, 1995; Helfert, 1994; Penman, 2001). In this paper we tried to indentify the relationship between application of electronic commerce and operational performance as part of organizational performance. According to Carton and Hofer (2006) operational performance can be further subcategorized into market share, new product introduction, product/service quality, marketing effectiveness and customer satisfaction. So, Hypotheses of this study are tested in the form of one main hypothesis and five sub-hypotheses.

H1- E-commerce Applications have a significant and positive impact on operational performance in small and medium enterprises

H1.1- E-commerce Applications have a significant and positive impact on market share in small and medium enterprises

H1.2-E-commerce Applications have a significant and positive impact on new product introduction in small and medium enterprises

H1.3-E-commerce Applications have a significant and positive impact on product/service quality in small and medium enterprises

H1.4- E-commerce Applications have a significant and positive impact on marketing effectiveness in small and medium enterprises

H1.5- E-commerce Applications have a significant and positive impact on customer satisfaction in small and medium enterprises

\section{Figure1: Research model}

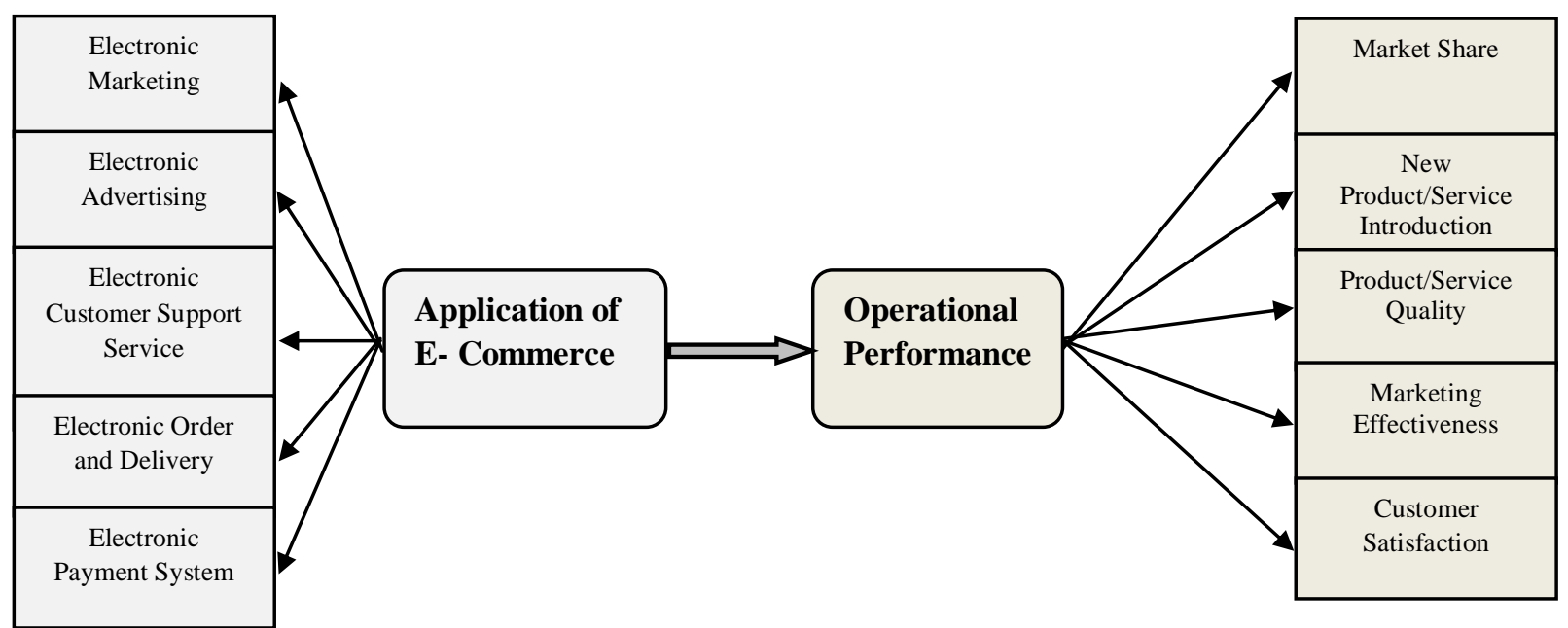

\section{Methodology of the Study}

The purpose of this research was to explore possible relationship between the application of e-commerce and the organizational performance in Indian SMEs. The study employed survey research to determine whether an impact exists between the dependent variable-application of e-commerce-and the independent variable-operational performance.

The present study because of dealing with testing the effect of Application of E-commerce variable on operational performance variable (including: Market Share, New Product / Service Introduction, Product / 
Services Quality, Marketing Effectiveness and Customer Satisfaction) and develop practical knowledge about the quality of relation and effectiveness between these two variables, from the aim and objectives view point is practical and from method of data collection and analysis view point is descriptive and is of correlative type.

Population, Sample, and Data Collection Procedure: The questionnaire comprised three main sections. The first section asked the respondents about their personal information. The second section contains 21 statements measuring the five applications for E-Commerce: Electronic Marketing, Electronic Advertising, Electronic Customer Support Service, Electronic Order and Delivery, and Electronic Payment System. These statements are formulated by ((Turban et al. (2000); Ainin, and Jaffar, (2003); Ainin, (2000); Kotler, (2000); Smith \& Chaffey (2005); Soh et al. (1997)). Respondent were asked to indicate their extent of agreement using a five point likert scale (with $5=$ completely agree, to $1=$ completely disagree). For these questions the Cronbach's Alpha coefficient of 0.85 has been calculated. The third section contains 15 statements measuring the five Operational Performance dimensions: Market Share, New Product/Service Introduction, Product/Service Quality, Marketing Effectiveness and Customer Satisfaction. These statements are formulated by (Carton and Hofer, 2006; Combs, et al., 2005; Brealey et al., 2001; Higgins, 1995; Helfert, 1994; Penman, 2001). Respondent were asked to indicate their extent of agreement using a five point likert scale (where $5=$ extensively covered, to 1 = weakly covered). For these questions, the Cronbach's Alpha coefficient of 0.88 has been calculated and For analyzing data derived from questionnaire Structural Equation Modeling / Path Diagram has been used. In this study, we used Stratified Random Sampling for collect necessary data. The population of the research will be all the small and medium enterprises in Pune which are using electronic commerce and own internet website which is estimated to be 395 units. Out of 395 units, a sample of $120 \mathrm{SME}$ units is to be taking to obtain the primary data. Therefore, 150 questionnaires have been distributed in 3 months period between population samples randomly. After several attempts, only 135 responses were collected. Through the data screening process only 121 responses found to be usable for further analysis. Among all respondents, $44.9 \%$ people have management-related education and $25.6 \%$ people have information technology-related education.

\section{Results of the Study}

Goodness of Fit Tests: Given that structural equation modeling has no single statistical test of significance for model fit, several goodness-of-fit measures were used to assess the fit of model. The relative chi-square (chi-square/degree of freedom; $\chi^{2} / \mathrm{df}$ ), standardized root mean square residual (standardized RMSR), goodness-of-fit index (GFI), adjusted goodness-of-fit index (AGFI), normed fit index (NFI), and comparative fit index (CFI) were used as goodness-of-fit measures. Due to the sensitivity of the chi-sqare test to sample size, the relative chi-square was used (it should be 3.0 less for an acceptable model) (Tomer \& Pugesek, 2003), Standardized RMSR should not be greater than 0.10 and GFI, AGFI, NFI, and CFI should exceed 0.90 to be acceptable (Hair et al. 2006). The goodness of fit of a statistical model describes how well it fits a set of observations. The rate of each index has come in the table 4:

Table4: Goodness of fit tests

\begin{tabular}{ccccccccc}
\hline$\chi^{2}$ & $\begin{array}{c}\chi^{2} \\
/ \mathrm{df}\end{array}$ & $\begin{array}{c}\text { Root Mean } \\
\text { Square } \\
\text { Residual } \\
\text { (RMR) }\end{array}$ & $\begin{array}{c}\text { Goodness } \\
\text { of Fit } \\
\text { Index } \\
(\mathrm{GFI})\end{array}$ & $\begin{array}{c}\text { Adjusted } \\
\text { Goodness } \\
\text { of Fit } \\
\text { Index }\end{array}$ & $\begin{array}{c}\text { Root Mean } \\
\text { Square Error of } \\
\text { Approximation }\end{array}$ & $\begin{array}{c}\text { Normed } \\
\text { Fit Index } \\
\text { (NFI) }\end{array}$ & $\begin{array}{c}\text { Non- } \\
\text { Normed }\end{array}$ & $\begin{array}{c}\text { Compara } \\
\text { tive Fit }\end{array}$ \\
\hline 89.53 & 2.64 & 0.038 & 0.93 & 0.94 & 0.079 & 0.92 & 0.94 & $\begin{array}{c}\text { Index } \\
\text { (CFI) }\end{array}$ \\
\hline
\end{tabular}

The measurement model with all two constructs was using confirmatory factor analysis and t-value (Anderson \& Gerbing, 1992). Table 5 presents factor loading and the corresponding t-values of indicators in the measurement model. To be considered adequate, the individual item reliability should be greater than 0.50 (Joreskog \& Sorbom, 1996). The factor loading extracted should be at least 0.5 and the $t$-value should be greater than 1.96 (Bagozzi \& Yi, 1988). All indicators are significant at 0.05 levels (Level of confidence 95\%). The measurement model exhibited a good level of model fit. 
Table 5: Factor loading and t-values of the measurement model

\begin{tabular}{lcc}
\hline Construct/indicator & Factor Loading & t-value \\
\hline Application of E-Commerce & & \\
Electronic Marketing & 0.53 & 8.32 \\
Electronic Advertising & 0.51 & 13.31 \\
Electronic Customer Support Service & 0.60 & 13.95 \\
& & \\
Electronic Order and Delivery & 0.62 & 12.10 \\
Electronic Payment System & 0.80 & 9.52 \\
Operational Performance & & \\
Market Share & 0.53 & 8.68 \\
New Product/Service Introduction & 0.68 & 14.32 \\
& & \\
Product/Service Quality & 0.66 & 14.11 \\
Marketing Effectiveness & 0.55 & 11.63 \\
Customer Satisfaction & 0.50 & 8.23 \\
\hline
\end{tabular}

Only Electronic Marketing and Customer Satisfaction had item/indicator reliability below 0.50 but in table 5 the corresponding t-values were significant for all two. According to the results, fitness model is well.

Hypotheses testing using Structural Equation Modeling/Path Analysis: Structural equation modeling (SEM) is a powerful tool to explore and contrast hypotheses on causal relationships among variables using observational data. For all hypotheses of the study below hypothesis test was used.

$$
\left\{\begin{array}{cc}
\mathrm{H}_{\mathrm{o}} \alpha=\mathrm{o} & \text { Null hypothesis: Correlation between two variables is not significant } \\
\mathrm{H}_{1:} \alpha \neq 0 & \text { Alternative hypothesis: Correlation between two variables is significant }
\end{array}\right.
$$

To address the research questions and test the hypotheses, the percentages of explained variance (R2) for each endogenous variable and the path coefficients of the hypothesized model were assessed. As it is observed, diagram 1 shows structural model of the study for confirming main hypothesis (and subhypotheses) of the study.

\section{Diagram 1: Structural model of study for confirming main hypothesis}

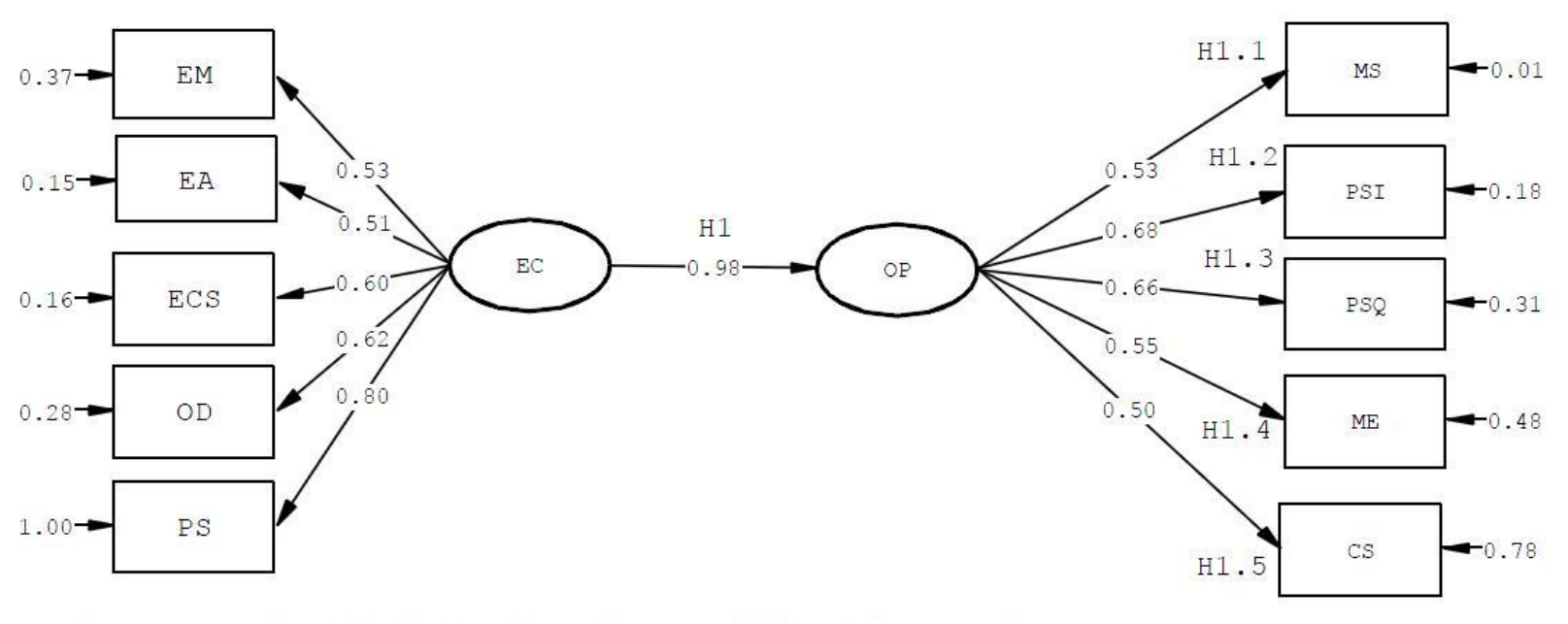

Chi-Square $=89.53, \mathrm{df}=34, \mathrm{P}$-value $=0.00000, \mathrm{RMSEA}=0.079$ 
Diagram 2 also shows significance and resulted parameters from main hypothesis test. Significance value of 14.93 for the main hypothesis was determined. Significance value of the main hypothesis is placed out of ($1.98,1.98$ ) interval, therefore, the formed relation is out of the null hypothesis and indicates the ratification of the main hypothesis of the research. According to results of these two models (relation is based on standard estimation of 0.98 and is based on significance equal to 14.93) hence, main hypothesis is confirmed.

\section{Diagram 2: Structural model of study for confirming main hypothesis}

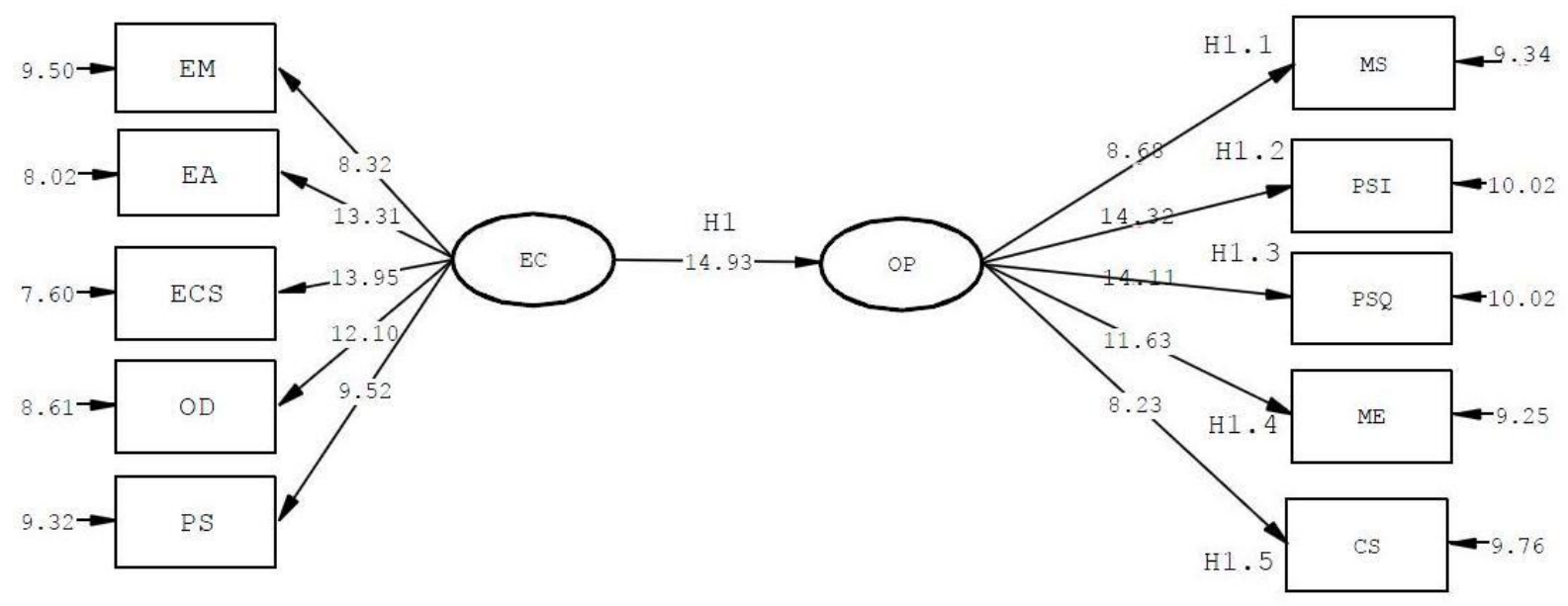

Chi-Square=89.53, $d f=34, P-v a l u e=0.00000, \quad$ RMSEA $=0.079$

Based on the analysis done using path analysis, results of testing the hypotheses of the study can be seen in table 6. Standardized coefficient and significance value in confirming or rejecting the hypotheses (significance of hypotheses) was used.

Table 6: Results of testing the hypotheses of the study using path analysis

\begin{tabular}{|c|c|c|c|c|c|}
\hline 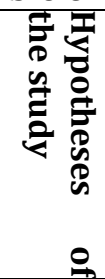 & & Path & 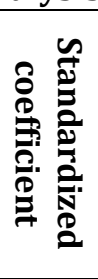 & 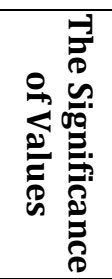 & 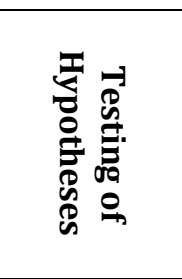 \\
\hline H1 & $\begin{array}{l}\text { Application for E- } \\
\text { Commerce }\end{array}$ & Operational Performance & 0.98 & 14.93 & Confirmed \\
\hline $\mathrm{H}_{1.1}$ & $\begin{array}{l}\text { Application for E- } \\
\text { Commerce }\end{array}$ & Market Share & 0.86 & GOOD & Confirmed \\
\hline $\mathrm{H}_{1.2}$ & $\begin{array}{l}\text { Application for E- } \\
\text { Commerce }\end{array}$ & $\begin{array}{l}\text { New Product/Service } \\
\text { Introduction }\end{array}$ & 0.96 & GOOD & Confirmed \\
\hline $\mathrm{H}_{1.3}$ & $\begin{array}{l}\text { Application for E- } \\
\text { Commerce }\end{array}$ & Product/Service Quality & 0.78 & GOOD & Confirmed \\
\hline $\mathrm{H}_{1.4}$ & $\begin{array}{l}\text { Application for E- } \\
\text { Commerce }\end{array}$ & Marketing Effectiveness & 0.86 & GOOD & Confirmed \\
\hline $\mathrm{H}_{1.5}$ & $\begin{array}{l}\text { Application for E- } \\
\text { Commerce }\end{array}$ & Customer Satisfaction & 0.97 & GOOD & Confirmed \\
\hline
\end{tabular}

\section{Discussion and Conclusion}

Electronic commerce is a process whereby organization share and exchange information, maintain relationships and conduct business transactions using technologies. Such activities carried out by organizations or businesses basically involved in five different business processes or activities, namely, advertising, marketing, order and delivery, payment and customer support and services. On the other hand, 
operational performance as a part of organizational performance can be further subcategorized into market share, new product introduction, product/service quality, marketing effectiveness and customer satisfaction. Researchers such as (e.g. Wang, et al., 2009; Mazandarani, 2010; Duffy, 2005; Molla and Licker, 2001; Hua and Guan, 2000 and Senn, 2000) argued that e-commerce applications in the industrial and service sector has great impact on improvement of the different sections of the organizational performance. From the Operational perspective e-commerce offers a quick move for the success of business. Results of the present research hypotheses clearly ratified the above said claims. Results of fitness indicators of the model show that the proposed model is confirmed. Therefore, the proposed model was suitably able to place the variables of the study and show their relationship with their dimensions. According to statistical analysis in this research the results indicates that the electronic commerce applications have a significant and positive impact on operational performance in Indian SMEs.

\section{References}

Aba-bulgu, M., \& Islam, S. N. (2007). Corporate crisis and risk management: modeling, strategies and SME application. International business and management. Elsevier, London, UK.

Ainin, S., \& Jaffar, N. (2003). E-Commerce Stimuli and Practices in Malaysia. 7th Pacific Asia Conference on Information Systems, 10-13 July 2003, Adelaide, South Australia.

Ainin, S. (2000). Status of E-Commerce Application in Malaysia, Information Technology for Development Journal, 9(3/4), 153-161.

Allen, E., \& Fjermestad, J. (2001). E-commerce Marketing Strategies: an Integrated Framework and Case Analysis. Logistics Information Management. 14(1/2), 14-23.

Anderson, J. C. \& Gerbing, D. W. (1992). Assumptions of the two-step approach to latent variable modeling. Sociological Methods and Research, 20(3), 321-33.

Afshar J. A., Bairagi, K. P., \& Khaksar, S. M. S. (2010). The Application of electronic commerce among small and medium enterprises: from business processes view, International Journal of Business and Social Science, 2(5), 142-148.

Afshar J. A., \& Nawaser, K. (2010). Mobile commerce: the force of electronic commerce future. International seminar on 'innovations in strategic management for organizational excellence, Sinhgad institute of management. Pune, India.

Arie S., Dadong, W. \& Caroline, B. (1995). Financial EDI over the Internet: a Case Study. Working Paper CITMWP-1006. Fisher Center for Information Technology \& Management, University of California in Berkeley.

Bagozzi, R. P., \& Yi, Y. (1988). On the evaluation of structural equation model, Journal of Academy of Marketing Science, 16(1), 74-94.

Barker, N. (1994). The Internet as a reach generator for small business. Unpublished master's thesis, University of Durham.

Berrill, A., Goode, S. \& Hart, D. (2004). Managerial expectations of internet commerce adoption after the "tech wreck" of 2000-an Australian perspective, Journal of Global Information Technology Management, $17(3), 45-63$.

Brealey, R.A., Myers, S.C., \& Marcus, A.J. (2001). Fundamentals of Corporate Finance (3rd edn), New York: McGraw-Hill.

Block, M., Yves, P., \& Arie S. (1996). On the Road of Electronic Commerce- a Business Value Framework, Gaining Competitive Advantage and Some Research Issues, Working Paper: Fisher Center for Information Technology and Management, University of California, Berkeley.

Burns, P. (2001). Entrepreneurship and Small Business. Palgrave, Hampshire, UK.

Carton, R. B. \& Hofer, C. W. (2006). Measuring Organizational Performance: Metrics for Entrepreneurship and Strategic Management Research, Edward Elgar Publishing Limited.

Combs, J. G., T. Crook, R., and Christopher, L.S. (2005). The dimensionality of organizational performance and its implications for strategic management research, in Professor David Ketchen and Professor Don Bergh (ed.) Research Methodology in Strategy and Management (Research Methodology in Strategy and Management), Emerald Group Publishing Limited, 2, 259-286.

Cockburn, C., \& Wilson, T. D. (1995). Business use of the World-Wide Web. from Web: http://informationr.net/ir/1-2/vaperó.html. 
Cronin, B., Overfelt, K., Fouchereaux, K., Manzvanzvike, T., Cha, M., \& Sona, E. (1994). The Internet and competitive intelligence: A survey of current practice. International Journal of Information Management, 14(3), 204-222.

Duffy, D. L. (2005). Affiliate marketing and its impact on e-commerce, Journal of Consumer Marketing, 22(3), 161-163.

Dyer, L., \& Reeves, T. (1995). Human resource strategies and firm performance: What do we know and where do we need to go? Paper presented at the 10th World Congress of the International Industrial Relations Association, Washington, DC.

Eid, M. I. (2011). Determinants of E-Commerce Customer Satisfaction, Trust, and Loyalty in Saudi Arabia. Journal of Electronic Commerce Research, 12(1), 78-93.

Fahri, K. \& Omar, K. (2001). Electronic Commerce Use in Small and Medium-Sized Enterprises in Towards the E-Society E-Commerce, E-business, E-Government, edited by Schmid, B, Stanoevska, K and Tschammer, V, Kluwer Publishing, Zurich.

Fatimah, M. A., Kusairi, M. N., \& Mohd, F. A. (2000). E-commerce Adoption in Malaysia: Problems and Barriers from the Firms' Perspective, International Conference on Electronic Commerce Proceedings, 21-23 November, Kuala Lumpur.

Fuller, T., \& Jenkins, A. (1995). Public intervention in entrepreneurial innovation and opportunism: short cuts or detours to the information superhighway? In proceedings of the babson entrepreneurship conference, London, UK.

Gupta, R. (2006). Scope of Cottage and Small Scale Industry in West Bengal in the Early 2000, IBS Research Centres, Kolkata.

Ghatak, S. (2010). Micro, Small and Medium Enterprises (MSMEs) in India: An Appraisal, available from: http://zunia.org.

Johnson, C. (2003). U. S E-commerce: the year in review, Cambridge, MA: Forrester Research.

Hair, J., Black, W. C., Babin, B. J., Anderson, R. E. \& Tatham, R. (2006). Multivariate Data Analysis, Pearson Education, New York.

Helfert, E. A. (1994). Techniques of Financial Analysis (8th edn), Boston, MA: Irwin.

Higgins, R.C. (1995). Analysis for Financial Management (4th edn), Boston, MA: Irwin.

Hua, F. \& Guan, S. U. (2000). Agents and Payment Systems in E-commerce. In Rahman, S.M. and Bignall, R.J. (Eds.), Internet Commerce and Software Agents: Cases, Technologies and Opportunities, IDEA Group Publishing, 317-330.

Joreskog, K. G. \& Sorbom, D. (1996). LISREL 8: Structural Equation Modeling, Scientific Software International Corp., Chicago, IL.

Kalakota, R., \& Robinson, M. (1999). E-Business: Roadmap for Success. Sydney, Addison Wesley.

Kotler, P. (2000). Marketing Management. 10 th ed., New Jersey, Prentice-Hall.

Kraemer, K., Gibbs, J. \& Dedrick, J. (2002). Impacts of globalization on e-commerce adoption and firm performance: A cross-country investigation, Globalization and E-Commerce. Irvine, centre for research on information technology and organizations.

Lawal, A. S. (2010). Electronic commerce in Nigeria banking industry (a case study of guaranty trust bank Nigeria plc.) department of business administration, faculty of business and social science, university of Ilorin, Ilorin.

Marg, K. S. K. (2001). Facilitating innovation in Indian small and medium enterprises-The role of clusters, Current science, $80(3)$.

Mazandarani, M. (2010). Comparison of the Type of the Web Base Advertising on Ecommerce Improvement. Journal of American Science, 6(3), 150-156.

Molla, A., \& Licker, P. S. (2001). E-Commerce Systems Success: An Attempt To Extend And Respecify The Delone And Maclean Model Of Is Success. Journal of Electronic Commerce Research, 2(4), 131-141.

MSME. (2009-10). Ministry of Micro, Small and Medium Enterprises, Government of India, Annual Report 2009-10, Chapter I, P1, available from: http://msme.gov.in/MSME_AR_ENG_2009_10.pdf.

Nickels, D.W., Kwun O., and Omar, A. (2007). The effect of organizational culture on e-commerce adoption. From: http://www.swdsi.org/swdsi08/paper/SWDSI\%20Proceedings\%20Paper\%20S152.pdf.

Oakes, C. (2002). Successful E-commerce means going back to the basics. International Herald Tribune, 24(12).

Poon, S., \& Huang, X., (2004).E-Commerce and SMEs: A Reflection and the Way Ahead. Idea Group Inc. Charles Sturt University, Australia. 
Poon, S., \& Swatman, P. M. C. (1995). The Internet for small businesses: An enabling infrastructure for competitiveness. Paper presented at the Fifth Internet Society Conference, Hawaii, USA.

Penman, S.H. (2001), Financial Statement Analysis and Security Valuation, New York: McGraw-Hill.

Pierre J.R., Timothy M.D., George S.Y., \& Gerry J. (2009). Measuring Organizational Performance: Towards Methodological Best Practice. Journal of Management. 35(3), 718-804.

Ravi, S., (2009), Entrepreneurship Development in the Micro Small and Medium Enterprise Sector in India, Indian School of Business. From: http://www.isb.edu/faculty/shamika /MSME\%20chapter_Shamika\%20Ravi.PDF.

Raymond, L. (2001). Determinants of Web site implementation in small business. Internet Research: Electronic Network Applications and Policy, 11(5), 411-422.

Seyal, A. H., \& Rahman, M. N. A. (2003). A preliminary investigation of e-commerce adoption in small \& medium Enterprises in Brunei. Journal of Global Information Technology Management, 6(2), 6 - 26.

Schaper, M., \& Volery, T. (2004). Entrepreneurship and small business: A Pacific Rim perspective. Singapore: Wiley.

Senn, J. A. (2000). Business-to-business e-commerce. Information Systems Management, 17(2), 23-32.

Soh, C., Quee, M., Fong, G., Chew, D. \& Reid, E. (1997). The use of the Internet for business: the experience of early adopters in Singapore, Internet Research: Electronic Network Application and Policy, 7(3): 217228.

Smith, P.R., \& Chaffey, D. (2005). E-marketing Excellence: at the Heart of E-business, 2nd edn. Butterworth Heinemann Elsevier, Oxford.

Shaker, T. I. and Basem, Y. A. (2010). Relationship Marketing and Organizational Performance Indicators. European Journal of Social Sciences, 12(4): 545-557.

Stroehle, F. (2008). Effective E-Commerce in China Lessons from cross-cultural research. Otago Management Graduate Review, 6, 65-79.

Tomer, A. \& Pugesek, B. H. (2003). Guidelines for the implementation and publication of structural equation models. In: Pugesek, B.H., Tomer, A., von Eye, A. (Eds.), Structural Equation Modeling: Applications in Ecological and Evolutionary Biology. Cambridge University Press, Cambridge.

Turban, E., Lee, J., King, D., \& Chung, H. (2002). Electronic commerce: A managerial perspective, NJ, Prentice Hall.

Turban, E., McLean E. \& Wetherbe, J. (2000). Information Technology for Management, NY: John Wiley \& Sons. Inc.

Upkar, V. (2002). M- commerce: framework, applications and networking support, Kluwer Academic Publishers Hingham, MA, 7(1), 185-198.

Venkatraman, N., Ramanujam, V. (1986). Measurement of Business Performance in Strategy Research: A Comparison of Approaches. The Academy of Management Review, 11(4), 801-814.

Wang K., Wang, E. T. G., \& Farn, C. K. (2009). Influence of web advertising strategies, consumer goaldirectedness, and consumer involvement on web advertising effectiveness, International Journal of Electronic Commerce, 13(4), 67-95.

Zwass, V. (1998). Structure and Macro- Level Impacts of Electronic Commerce, CA: Saga Publication. 